Portland State University

PDXScholar

$1-2020$

\title{
Proper Conjugation of Bodies: Chastity, Age, and Care Work in Sri Lankan Migrants' Families
}

Michele Ruth Gamburd

Portland State University, b5mg@pdx.edu

Follow this and additional works at: https://pdxscholar.library.pdx.edu/anth_fac

Part of the Social and Cultural Anthropology Commons

Let us know how access to this document benefits you.

\section{Citation Details}

Published as: Gamburd, Michele R. 2020. "Proper Conjunctions of Bodies: Chastity, Age, and Kin-work in Sri Lankan Migrants' Families." In The Migrant's Body in Asia: Ethnicity and Race, Gender and Sexuality, edited by Michiel Baas. 135-160. Amsterdam: Amsterdam University Press.

This Post-Print is brought to you for free and open access. It has been accepted for inclusion in Anthropology Faculty Publications and Presentations by an authorized administrator of PDXScholar. Please contact us if we can make this document more accessible: pdxscholar@pdx.edu. 


\title{
CHAPTER 6
}

\section{Proper Conjugation of Bodies: Chastity, Age, and Care Work in Sri Lankan Migrants' Families}

\author{
Michele Ruth Gamburd \\ Portland State University \\ b5mg@pdx.edu
}

\begin{abstract}
Physical and symbolic aspects of bodies limit the migration trajectories of female domestic workers from a Buddhist community in coastal Sri Lanka. Government regulations and family decisions regarding women's overseas labour draw upon and in turn influence discourses about gender, sexuality, age, health, and class. This ethnographic analysis illustrates that local norms task women with nurturing the brains of babies, preserving the chastity of teenage daughters, caring for frail elders, and preventing their working-class husbands from overindulging in liquor or having sex with other women. Successful social reproduction depends on the proper conjunctions of bodies in the extended family. Corporeal and symbolic dangers imagined to arise from women's absence fuel a nationallevel moral panic about female migration.
\end{abstract}

\section{Keywords}

Migrant domestic workers, female overseas labour, chastity, social reproduction

\section{Introduction}

Women have migrated from Sri Lanka to work in the Middle East for the past thirty years as temporary labourers (B. Brown 2011; Frantz 2008; Gamburd 2000; Näre 2010). Large numbers of female migrants work as domestic servants in Saudi Arabia, Kuwait, and the United Arab Emirates. These working-class 'housemaids' make up the vast majority of migrant Sri Lankan women (SLBFE 2017).

Since this trend in labour migration began, social commentators have lamented the risks posed to women and the social costs borne by their families. At times, concerns have reached the level of 'moral panic', when the unethical behaviours of or potential dangers to a particular group of people purportedly threaten the very foundations of society (Lynch 2007). For example, an editorial in the Daily Mirror (2015a, A8) entitled 'Stop the Abuse of Lankan Mothers and Girls' sums up what Sri Lankans supposedly 'know' about the situations (and bodies) of migrant women and their family members: 
About one million young Sri Lankan mothers and girls ... go to the Middle East for work. Reports say most of them are required to work like slaves for about 20 hours a day ... Reports indicate that thousands of Sri Lankan women and girls are sexually abused by the men in the families which they work for. In many cases there are tragedies in the families here also when the mother goes away leaving the father with young daughters to look after. Often there had [sic] been reports of sexual abuse leading to the break up [sic] of thousands of families. (Daily Mirror 2015a, A8).

In this chapter, I focus on concerns about migrants' bodies, examining how local discourses both enable and limit migration. Using a life course analysis, I extend the focus outward to include not only the migrant's body but also the bodies of the migrant's younger and older kin.

Decisions about migration take place within family relationships. Sometimes those relations are egalitarian and reciprocal; at other times they are hierarchical and asymmetrical (Zhou 2017: 46). Family members coordinate productive and reproductive capacities in order to achieve the reproduction of the family as a whole, generating sufficient income and assuring physical care for all members (D. Brown 2013; Huijsmans 2013). In this way, household members living in Sri Lanka still participate in the dynamics of transnational migration (Ibarra 2002). Not only does transnational migration affect the family; reciprocally, family structures and strategies affect who can and does migrate.

Life course analysis examines how people move through stages of their life (LloydSherlock and Locke 2008; Locke, Seeley, and Rao 2013). Migrant families deploy their members strategically to meet the care needs of youngsters and elders (Cole and Durham 2007; Douglass 2014). To understand the migration decisions made in the case studies that follow, I explore bodily issues related to youngsters (developing cognition and character, 
studying), teenagers (reaching puberty, engaging in love affairs), mature individuals (marrying, bearing children, working), grandparents (looking after grandchildren, facing illnesses), and frail elders (contributing as able to the family, but also requiring and receiving physical care).

One person's stage of life will affect the opportunities open to their kin at other stages of life. In the case of Sri Lankan transnational migrant labourers, in order for a migrant to go abroad, the family needs to consider bodily and emotional needs of three and sometimes four generations of kin-a process of coordination that researchers refer to as 'kin timing' (Dossa and Coe 2017: 12). For example, a woman might be able-bodied and ready to work as a domestic servant in the Persian Gulf, but if she is nursing a baby, or if her teenage daughter has reached puberty, or if she needs to take care of a frail elder, the situation may prevent her migration. People evaluate stages of life, care-giving duties, and migration decisions within cultural contexts.

Decisions around migration carry moral implications. Kin understand that one ought to care (and care well) for all members of the family, providing physical and social support as well as financial stability (Whyte 2017: 245). People evaluate decisions about migration in light of social norms about what 'good' care and 'good' families should look like and how families should distribute 'kin work' between members (Dossa and Coe 2017: 9). However, given changing contexts (such as the high cost of living, new state policies in Sri Lanka and in the Gulf, demographic transformations in the population structure, and evolving norms about gender and sexuality), families find it difficult if not impossible to replicate social ideals in practice. Contradictions lead to cognitive dissonance and emotional distress, which in turn can fuel negative discourses about families and migration.

As the analysis in this project illustrates, migration decisions are deeply gendered, aged, and classed. These culturally constructed identities influence how people see, judge, and make decisions about bodies and whether they should cross borders. The mobility of a 
migrant depends on the state of other bodies in the family, some of whom (e.g., vulnerable female teenagers or frail elders) need the sort of care that only the would-be migrant woman can offer. Examining the cultural understandings of bodies in migrant households reveals much about the policies and discourses surrounding transnational labour in Sri Lanka.

\section{Research Methods and Context}

I gathered data for this chapter in Sri Lanka, in the village that I call Naeaegama, during three separate month-long visits between 2015 and 2017. (I use pseudonyms when referring both to the village and to my research interlocutors.) Having worked as a cultural anthropologist in this village for over 25 years, I drew on my longitudinal ethnographic experience with issues of migration, gender, and family relationships (Gamburd 2000, 2005, 2013, 2015). During the fieldwork in question, I performed interviews and participant observation on topics related to migration and population aging. I did not set out to examine the topic of 'bodies' in particular, but I have found in retrospect that my data contain rich information on this subject. For this chapter, I rely on roughly fifty interviews with individuals and small groups. Some of the individuals spoke with me more than once. I use grounded theory methods to decipher emerging themes in the data, and I illustrate those themes with exemplary cases and quotes (Bernard 2011).

The village of Naeaegama, located about fifty miles from the capitol city of Colombo on Sri Lanka's southwest coast, is home to roughly 1250 individuals. Since the late 1980s, a large number of women have migrated to the Persian Gulf as domestic workers, employed on consecutive 2-year contracts. Men also worked abroad, but from the late 1980s until the early 2010s, women made up the majority of migrants (SLBFE 2017: 2). In recent years, more men and fewer women have worked abroad. In Naeaegama, at least a quarter of village families have had some experience with transnational labour migration. These trends mirror national statistics over the years in question (SLBFE 2017). Other local occupations for 
women include working in factories, offices, and schools, as well as engaging in small business activities (often related to processing coconut fibre for rope and brooms). Job opportunities for men include holding positions in the armed services, offices, and schools; working in the tourism industry; driving three-wheel taxies; peeling cinnamon; engaging in day labour; and peddling and making coconut fibre brooms.

\section{Moral Panic in the Newspapers}

For many years, 'horror stories' (Gamburd 2000) have fed a low-level moral panic regarding the adverse effects of transnational female labour migration. In Sri Lanka, discussion of working-class women's migration takes place within a discourse filled with patriotic protectionist rhetoric and negative assessments of the social costs for migrants' families. When analysing moral panic discourses, and particularly when critiquing discourses about violence against women and girls, one runs the risk of appearing to support whatever the discourse in question condemns. I in no way wish to suggest here that I condone any violence against migrants or that I dismiss possible bad consequences that might arise for migrants' families. In analysing the texts and interviews discussed below, I highlight the underlying assumptions about gender, sexuality, age, and class. I argue that the assumptions in the discourse do not match on-the-ground realities in Naeaegama. These false assumptions, however, provide fundamental support for national policies that undermine women's mobility and employment opportunities. Although couched in the form of protections for migrants and their families, the policies limit and damage life options. Discourses bear fruit for those who deploy them, particularly because the narratives can 'ward off morally and politically uncomfortable questions' (Biolsi 2007: 403). In this case, discourses about gender, sexuality, age, and class help shape local social structures and state migration policies that control women's bodies and limit their access to work in the international economy. 
Discourses about dangers to working-class migrant women have circulated in Sri Lanka for years, and the general public accepts them as fundamental 'truths' about labour migration. Many aspects of these discourses focus on bodies. The most compelling recent story, which circulated internationally and still reverberates in Sri Lanka today, deals with the 2013 beheading in Saudi Arabia of Rizana Nafeek, a Sri Lankan housemaid condemned for allegedly strangling a four-month-old baby under her care in 2005 (Evans 2013). Local scholars and residents of Naeaegama point to this brutal incident of corporal punishment as a watershed moment leading to restrictions for women in Sri Lanka's international migration policy.

Several prevalent themes shape both local conversations and media coverage of women's migration to the Middle East. Aside from the threat of execution, concerns also focus on the sexual risks related to female employment abroad. A recent newspaper article asks whether job agents make contraception mandatory for women migrants, and notes that Depo-Provera injections would 'serve a double purpose: covering up potential sexual assaults by recruitment agents and serving as a guarantee to prospective employers that workers will not get pregnant'; it also suggests that 'some women think it's necessary to have sex with agents to go abroad' (Sunday Observer 2018: 17). Women's vulnerability to sexual abuse forms a key aspect of the moral panic discourse.

Small but ubiquitous newspaper articles highlight the lack of control women have over their working conditions. For example, a short article (Daily Mirror 2015b, A4), provocatively headlined 'Employer Offers SL Maid For Sale Online in Saudi', notes that an employer had sought, with his housemaid's knowledge and support, to transfer her work visa to another sponsor in exchange for covering the associated fees. Some parties in the overseas discussion viewed this transaction as a process of 'trading in humans' (Daily Mirror 2015b, A4), deeming it inappropriate to exchange money for human lives. Along a similar line, a reporter quotes a government minister who, while discussing the US\$ 7 billion in 
remittances sent by migrant workers in 2015, noted 'Remittances is [sic] the hard work of poor workers; [sic] particularly mothers, wives, and sisters who are being tortured and killed, and commit suicide' (Wettasinghe 2015: 1). These materials lay out the dangers to Sri Lankan women's bodies that the authors hope state institutions and policies will prevent. Harm to the bodies of their children left at home forms another major theme in the discourse about risks associated with labour migration. For example, an article discusses the suspected sexual abuse of an eight-year-old school girl by her mother's brother; while the girl's mother worked abroad, the child lived in the care of her grandmother (Sugathapala 2015, A5). In a full-page newspaper article (with key terms printed in bright pink) regarding issues related to the then-ongoing election campaign, another author outlines the platform of one of the contending political parties, noting that they have pledged to 'Accept the protection of children of women migrant workers as a State responsibility [and] take protective action at state level against abuse, maltreatment and injustice suffered by women working abroad' (Chandratilleke 2015: 10). These and other articles like them in the moral panic genre exert political pressure on elected officials to do something to address the dangers that women and their children face. The suggested polices often reinforce existing patterns in identity politics related to gender, class, age, and sexuality. Mobilizing a discourse of danger helps to justify political projects that might not otherwise garner public support by manipulating readers' ethical and emotional sensibilities. As Williams explains, 'common sense' is a powerful form of hegemony (1977).

What actually happens to migrant men's and women's bodies when they are abroad? Statistics gathered by the Sri Lankan Bureau of Foreign Employment (SLBFE) do mention abuse, which forms the overwhelming topic in the moral panic genre. However, physical and sexual abuse constitutes a relatively small fraction $(18 \%)$ of the overall complaints filed by women in 2013 , which also include non-payment of wages $(17 \%)$, lack of communication (14\%), sickness (16\%), and breach of employment contract (13\%) (SLBFE 2014). Cases of 
sexual abuse may be underreported, due to people's worries about the effects on their reputations (which I discuss later); nonetheless, the discourse grants disproportionate importance to sexual vulnerability.

This preceding short selection of newspaper articles illustrates key elements of the discourse about working-class migrant women's work situations, their family relations, and the bodies of people in their households at home and abroad. In what follows, I put the moral panic discourse into conversation with concerns reported by migrants themselves. By presenting ethnographic information, I hope to nuance the discourse found in the Englishlanguage newspapers with the values and considerations expressed by migrants and their families in Neaegama.

\section{Food Practices as Indicators of Cultural Differences}

In discussing bodily practices, issues of food sustain nearly as much importance as issues of sexuality. Although the dominant social discourse focuses on issues of women's promiscuity and vulnerability to harassment and abuse, I found that in Naeaegama, migrants themselves often related stories about a category of bodily discomfort not covered in the SLBFE statistics or the newspaper reporting: incompatible culinary practices.

Many complaints I heard from returned migrants about living abroad centred around diet. Sri Lankan housemaids often encountered difficult situations regarding food. One housemaid, Kamala, who in 2015 was 46 years old and had spent 21 years abroad, told me about the troubles she faced in the late 1990s. Her employers would not even let her eat the family's leftovers. In much of South Asia, leftovers represent a low-status food; in Sri Lanka, one would rarely deny such sustenance to a dog, let alone to a person. The housemaid left that house and later found a much better employer who allowed her to eat as much as she wanted and needed. 
Another migrant focused on bodily functions to compare the behaviour and ethics of Sri Lankan housemaids with their female employers in the Persian Gulf. Jayanthi, a returned woman migrant who spent 22 years abroad in Dubai (UAE) and Saudi Arabia, suggested that Saudi women did not like to breastfeed; instead, they poured their milk down the sink. In her job, Jayanthi looked after five children between the ages of one and nine. She said that their own mother was 'never around'. By mobilizing an example based on nursing, a basic food-based bodily function of mothering, she suggested that Saudi women were unnatural mothers. By implication, she argued that the Sri Lankan housemaids working abroad gave better care than their own biological mothers did to their charges. Jayanthi's argument implicitly works against discourses (which I discuss below) that suggest that migrant women are bad mothers.

Food also provided a source of discomfort for Ramani, an experienced migrant who, when I spoke to her in 2016, had just returned from two years in Saudi Arabia. Ramani was a vegetarian, but the family of ten that she worked for consumed meat. She regularly cooked and served entire goats for the family. The carcasses arrived from the butcher with the head cut off, the skin removed, and the guts cleaned. Ramani estimated that the family ate seven or eight goats a week, including the tongue and brains; she had to cut the skull to remove these parts for consumption. Killing any animal for meat goes against the tenets of Theravada Buddhism, the religion practiced in Naeaegama, where people often eat fish, sometimes eat chicken, but rarely if ever consume red meat. Ramani said that she went hungry on the days that the family ate goat. The culinary scenario that Ramani described made her uncomfortable, and my research associate expressed his sympathy through grimaces and exclamations of disgust during this section of the interview. 
Concomitantly, Ramani reported that the lady of the house (or 'madam', as housemaids often refer to their female employers) suffered from a number of lifestyle illnesses, including diabetes, high cholesterol, and high blood pressure. Ramani brought seeds for bitter gourds (thought to have curative properties) with her from Sri Lanka. She planted, harvested, and cooked bitter gourd for her employer, but the employer refused to eat more than a tiny bite of it, complaining that it was bitter.

The two related halves of Ramani's narrative illustrate deep cultural antimonies between Sri Lanka and the Gulf regarding which foods are ethical and healthy to eat. They also illustrate the hierarchy between the housemaid (who could not refuse to cook goat as instructed and who could not order her madam to eat healthy vegetables) and the employer (who could order the housemaid to cook food the housemaid found inedible and could refuse to eat food the housemaid deemed healing). The twin stories about goat and bitter gourd illustrate a series of dichotomies between meat vs. vegetables, disgusting vs. medicinal foods, and bad vs. good ethical and religious practice. Both women refused to eat the other's food. Their choices of ingestible substances indicated a wide gap between their respective cultures and social statuses.

\section{Concepts of Age, Health, and Gender: Government Criteria for Female Labour Migration}

Age constitutes a key aspect of bodily identity, and societies all over the world regulate people's activities according to categories of maturity. In June 2013, the Sri Lankan government implemented a labour migration policy that restricted female migration in a number of age-related ways (Ministry of Foreign Employment 2015). Known as the 'Family Background Report' policy, the government circular and its subsequent revisions put limits of migrant women's age (less than 55 , but over 21,23 , or 25 depending on country of destination). Local women pay careful attention to the age limits. For example, Lakmini 
commented that her sister, age 54, was current working abroad. The sister planned to stay abroad as long as she could, because after she returned to Sri Lanka, she would not be able to leave again legally as a housemaid. The age limits impeded long-term migrants from taking advantage of the connections and social capital that they had developed over their years of working abroad.

The Family Background Report policy also considered the age of a migrant's children. It prohibited the migration of women with children under the age of five and required women with children over the age of five but under the age of eighteen to go through a rigorous screening process to verify the presence in the household of suitable caregivers for the children. A local subagent, Kanthi, discussed the process of filing the required paperwork: 'You need the couple's marriage certificate, all of the kids' birth certificates, and signature of the person taking care of the kids, and that person's identity card, and the signature of the husband. There's so much paperwork that you get fed up!' The birth certificates and identity cards served to verify the ages of the people in question. In addition, the FBR form inquires about the caregiver's age and health status. In 2017, I spoke with a Development Officer at the local Divisional Secretariat. Her job included going to the homes of potential migrants to confirm the information on Family Background Reports. The Development Officer told me that the caregiver should be female and under the age of sixtyfive. The age restrictions surrounding children and caregivers created substantial impediments to female labour migration.

The official bodily criteria for migration include not only the ages of the migrant, her children, and the children's caregiver, but also the health of the migrant. According to the FBR policy, before migrant women can leave the country for work, they must successfully complete a medical examination for the cost of 7500 Sri Lankan Rupees (about US\$ 57 in mid-2015), obtained from approved medical institutions and submitted as part of the woman's visa approval process. Kanthi, the local subagent introduced above, told me, 'It 
takes three trips to get one woman sent abroad. It takes a day to do the medical. And sometimes there are problems and the women can't travel abroad. One woman I worked with was found to have diabetes, another had varicose veins, and a third had a thyroid problem. They didn't know about these problems until they did the medical exam! And a strong 23-year-old had a bad vertebra bone. She had no idea about that before the exam'. The results of their exams disqualified all of those women from working abroad. Relatedly, doctors abroad diagnosed a local migrant woman with diabetes; she had to come home. Going and remaining abroad depended on good health.

Resistance to the Family Background Report focused on gender rather than age or health. Feminist groups in the capital protested vigorously against the policy and took their complaints to Sri Lanka's Supreme Court and to the United Nations, but the policy remains in effect as of this writing (April 2019). Key objections to the policy include its naturalization of female caregiving roles, its demonization of fathers, its restrictions on the rights to travel and work, and its likely effect of driving migration into undocumented avenues (United Nations 2014, 2015). Less attention has focused on the ageist marginalization of the kin work done by grandparents, particularly grandmothers, over the age of sixty-five (Gamburd 2019). The Sri Lankan Bureau of Foreign Employment and Government Ministries supportive of the policy insist that it protects children from the social costs of migration (Daily News 2018). Others have critiqued the policy elsewhere at length (ILO 2018; Sunday Times 2013; United Nations 2015); here I wish to examine related discourses about bodies of migrants and members of their households.

The discourse justifying the Family Background Report policy relies on the argument that young children bear disproportionately the social and physical costs of migration. During our interview with the Development Officer at the Divisional Secretariat, she volunteered that 'Sri Lanka is suffering social problems because of the absence of migrant mothers'. She elaborated, noting that without mothers, children's education and other 
development suffered and families experienced problems. When I asked whether any research supported these claims, she smiled at me and said, 'No, we just know it is true'. The justifying discourse also relies on negative assumptions about the type of woman who attempts to go abroad. The Development Officer characterized such a migrant as 'someone who is divorced or separated from her husband, who is trying to escape loans, or who has a police case pending against her'. She summed up the category, saying 'They are not at a good level in the normal community'. Contrary to what I have found in over two decades of research on migration, the Development Officer clearly implied that the working-class women who migrate have questionable morality on sexual, financial, and care-giving fronts.

Local informants held contradictory views about the skills and worth of migrant mothers. One retired government servant argued against female migration by suggesting that no one cares as well for a child as his or her mother. This informant provided an example of a migrant's young child who was struck and killed by a train; the attending relatives had not paid close enough attention. A university-educated woman suggested that 'Children need their mothers to help their brains develop during their young years'. She made no mention of other adults who might conceivably stimulate a child's development. These examples support the importance of a mother's presence. The justification for the national migration policy appears in tandem with narratives about neglected bodies and psyches of children. At the same time, many informants thought relatively poorly about the class of women who might consider migrating. For example, the university-educated women introduced above noted that uneducated mothers needed state support in learning how to take care of their families. She felt that they were too lazy to get jobs locally. She saw such women as neither good mothers nor good workers.

The gendered discourse around migration suggests that merely by remaining in the home, women could prevent all manner of social ills. A number of informants told me that if women stayed home instead of migrating, they could keep their husbands from drinking, 
womanizing, and committing incest with their daughters. For example, a young married woman told me, 'Most of my neighbours are good, but in that house [gestures up the street], the wife works abroad, the husband drinks and shouts, and the daughter suffers'. In the absence of a woman to control the situation in the neighbour's house, my informant chose to construct an expensive cement wall to separate her property from theirs. A retired male painter asserted that if a woman stayed home, she could control her husband's drinking and channel any extra money away from liquor toward more worthy household expenses. This discourse, supported by some local examples, seems to suggest that migrant women, despite their laziness, potential moral turpitude, and lack of education, could by their mere presence transform their households in positive ways. In particular, women were tasked with regulating the bodies of their family: developing the brains of babies, keeping toddlers off the train tracks, preserving the chastity of teenage daughters, and preventing their workingclass husbands from overindulging in liquor or having sex with other women.

\section{Left-Behind Husbands}

Although images of migrant women contain both positive and negative aspects, discourses contain nothing but negative images of migrant women's husbands. The derogatory elements focus on inappropriate bodily practices related to sexuality and the ingestion of food and drink. In the absence of a wife to control a man's behaviour, the husband purportedly indulges all of his senses. A retired male house painter told me, 'While the wife works, the husband drinks and womanizes'. During a financial literacy training at the local Buddhist temple, a male instructor stated, 'They want the 1.5 lakhs [recruitment bonus; about US\$ 1,135 in mid-2015], so the guy says he can look after the kids, and the mother-inlaw ends up doing all the work. You know about this country's fathers ... [pause; audience 
laughter]'. People in Naeaegama and elsewhere in Sri Lanka accept these unflattering and often untrue stereotypes of working-class men as common sense.

Inappropriate male sexuality formed a cornerstone of the moral panic around female migration. The discourse about husbands implies that in addition to drinking, womanizing, and lazily not doing their share of work, these men also molest their younger female kin. I did not hear about actual cases of this type of problem in Naeaegama, but newspapers reported on the topic. For example, one short article entitled 'Schoolgirl Sexually Abused' reports, 'A young man was taken into custody on suspicion of sexually abusing an eightyear-old school girl. The suspect was [the] victim's maternal uncle . . Investigations revealed that the girl's mother had gone abroad for employment ... [and] the suspect's wife had deserted him' (Sugathapala 2015, A5). Similarly, an editorial in the Daily Mirror opines (2015, 25 July), 'In many cases there are tragedies in the families ... when the mother goes away leaving the father with young daughters to look after. Often there had [sic] been reports of sexual abuse' (Daily Mirror 2015a, A8). People do not expect men to control their urges, and they do not expect that grandparents can protect granddaughters from their fathers' predation. The master narrative suggests that without the mediating presence of wives and mothers, men's sexuality takes immoral turns. Discursively, women of the 'sandwich generation' that looks after both elders and youngsters are put in charge of regulating men's bodies: their drinking, their work, and their sex drive. Society blames any male misbehaviours on the absent women.

\section{Men's Bodies Abroad}

The dangers that men's bodies face abroad seem to mirror the concerns that arise around male bodies at home in Sri Lanka regarding liquor consumption, laziness, and anger management. I did not find any data in my fieldnotes about men's sexuality while abroad; 
interestingly, people in Naeaegama did not seem to worry about this issue. The absence of such data for men, and the overwhelming prevalence of such data for women, reveals the highly gendered nature of the sexual aspects of the moral panic.

Male alcohol use causes quite a bit of concern for female family members, not only when men live in the village (Gamburd 2008) but also when male migrants work abroad. In the Gulf, Muslim majority countries prohibit open consumption of liquor. However, one returned male migrant, Presanna, and his mother reported drinking related issues that had arisen in Italy. Presanna's entire family had spent many years in Naples. Initially his wife had gone to join her siblings; thereafter in 2002 Presanna followed her, and then in 2009 they brought their children. In 2015 he returned alone to Sri Lanka; the rest of his family stayed in Italy.

The family framed this man's return in terms of bodily issues. When I asked, 'Will you go abroad again?' Presanna replied, 'I don't think so. It is cold; I suffer there in the winter. And I'm in my 50s. Some of the jobs need to be done by young, strong people. I'd rather stay here. I have been there enough'. I asked his mother if she was happy to have her son back at home. She replied diplomatically, 'He's a bit sick'. Her son was franker; he confessed that he drank a lot while in Italy. His mother agreed. After her son left the room, she told me quietly that he had serious problems with his liver. Reading between the lines, it seemed to me that his drinking had jeopardized both his employment and his marriage. His family in Italy had sent him home to his mother because he could no longer work and they could no longer deal with his drinking and ill health.

Laziness came up repeatedly when people discussed male migrants' bodies. Pemawathie had raised her migrant daughter's three children for many years. One of the granddaughters had married into a family with connections in Italy. When I spoke with Pemawathie in 2015, her daughter, granddaughter, and grandson all lived in Italy. Of the grandson, Pemawathie frankly said, 'Shantha won't look after elders. He refuses to do so. 
He says that he is educated, and he doesn't want to touch shit. He does other small jobs. But the real jobs there in Italy are in elder care'. The granddaughter who remained in Sri Lanka noted with condemnation, 'My younger brother won't work. He's useless'. Earning money for the family constitutes a major dimension of men's intergenerational care obligations to their kin.

Other issues about uncontrolled male migrant bodies involve the use of physical violence and anger. A returned male migrant told me an elaborate story about several fights that he had had while in the Gulf area. He had engaged in (and been jailed for) a fight with a male Saudi citizen, and he had also fought with a Bangladeshi prison guard and ended up in the hospital for two weeks. He portrayed his physical aggression in both cases as a protest against the unjust situations that he encountered. He returned repeated in his well-crafted narrative to one image: the red blood running onto the white outfit from the nose of the Saudi man with whom he had scuffled. Although the outcome of this fight pleased my informant, female relatives deemed troublesome the men who drank, fought, or refused to work.

\section{Female Chastity and the Dangers of Becoming Disrespectable}

In contrast with worries voiced about male migrants' bodies, people rarely worried about women drinking alcohol, fighting, or refusing to work. Instead, women at home and abroad faced the bodily challenges of keeping in good health and preserving their chastity and reputation. The contrasting concerns reveal the gendered nature of the moral panic discourse.

Preserving an unmarried woman's virginity is a major concern for both the woman and her family. Mihirini Sirisena (2018) and Eshani Ruwanpura (2011) have both written about Sri Lankan university women's understandings of couple relationships and sexuality. Both scholars emphasize that single women should not surrender their virginity. If an 
unmarried woman loses her good reputation, her parents will find it difficult to arrange a marriage for her. Upwardly mobile, educated graduates and soon-to-be graduates carefully police their own behaviours and bodily boundaries in order to guard their respectability.

In Naeaegama, similar priorities for respectability govern the activities of young and middle-aged woman from both the middle and working classes. Women demonstrate great concern about exposing or parting their legs. For example, people looked askance at women who drove motorcycles until the recent importation of a type of small scooter that allows women to keep their legs together in a space between the handlebars and the seat. A retired female school teacher prefaced an interview in 2016 with a passionate condemnation of a young woman who had worn shorts to the local Buddhist temple. She assured me that Americans might accept such attire, but Sri Lankans found it questionable in general and highly inappropriate to wear at the temple. These standards echo what Sirisena (2018) and Ruwanpura (2011) found among Sri Lankan female university students, who avoided wearing anything too tight, too short, or too revealing.

Preserving the privacy of female bodies from male gazes at all ages forms a key priority in arranging suitable care in Naeaegama. For example, returned migrant Indrani noted that despite her brother-in-law's immensely helpful caregiving service to her family while she worked abroad, the presence of her mother-in-law was what made the family's childcare arrangements acceptable. Leaving children (especially girls) alone in a man's care was not appropriate. Similarly, speaking about her carework for her mother-in-law, a busy office worker noted that women understand other women's female parts. A man could not bathe an older woman. Indeed, when mothers or mothers-in-law require physical support for activities of daily living such as bathing, migrant women will return from abroad to provide this care.

Families go to great lengths to preserve the reputations of their female kin. For example, returned migrant and subagent Kanthi and her husband hosted all three of their 
daughters-in-law and eight grandchildren in their crowded, noisy home while their sons worked abroad. Living in the extended family home provided security for women who lacked the protection of their husbands. Similarly, the parents of Manel, a middle-aged divorced woman and return migrant, lived with her and her unmarried daughter to protect their reputations in the village. Most people felt that a divorce would reflect poorly on the family when they attempted to arrange a marriage for their children, and thus women with children often separated for long periods from their husbands without officially obtaining a divorce. Similarly, a retired cinnamon peeler and his wife lived with their separated daughter and her children until her children married; thereafter they moved in with another daughter to help her with childcare and provide security for her during the day when her husband was away at work. A family's prestige and well-being replies upon the good reputation of the women in the family, which kin seek to preserve even at the expense of uncomfortable living arrangements.

Arranging a good marriage depends on preserving the bride's reputation. To illustrate how this imperative affects migrants, I first discuss how chastity influences marriages in general. Consider, for example, a humorous interchange that I observed at a local Old Folks Home. My research associate, the director of the home, and a long-time resident had been talking about intergenerational duties between parents and children. The discussion turned to the topic of marriage. My research associate remarked, 'In the old days you needed land and a dowry, such as a wardrobe and a sewing machine, some jewellery and money. The potential in-laws would ask of the prospective bride whether she could cook and sew. Now parents just hand their kids a phone and say, "arrange it yourself!"' We all laughed at this portrayal of impossibly irresponsible parents. The director then replied, 'Yes, she finds her own husband, and then they get divorced. Sri Lankan families have declined because of these issues'. People imagine that flirting on the phone, a notoriously teenage practice that parents find difficult to curtail, presages other unsupervised contact 
between unmarried people of opposite sexes, which can lead to elopement or hasty marriages with unsuitable people whom families would not ordinarily accept as kin.

Parents often wash their hands of children who marry without parental approval. For example, Manel (the divorced woman introduced above) had done her best to shelter her daughters from social disapproval by having her parents live in her home. However, against Manel's wishes, her eldest daughter got involved with a German tourist, married him, and left for Europe. Eighteen days later, she returned to Sri Lanka. Thereafter she had an affair with a man from the Colombo suburbs and left the village. Manel remarked, 'Kids make their own suffering'. She did not have much contact with this daughter anymore, although if the daughter had agreed to an arranged marriage, it is likely that Manel would have offered her full support. In other words, inappropriate marriages threaten the social cohesion of the family.

Similarly, women suspected of having affairs lose the respect of local people. Villagers in Naeaegama expressed reservations about Pemawathie's granddaughter, Tharini, whom one neighbour termed 'not of good character'. Local gossip suggested that Tharini had had an affair; when I interviewed the young woman, she did not mention her own activities but said that her husband had been unfaithful on several occasions while she worked abroad as a housemaid. The couple had separated and reconciled several times before divorcing. Tharini sold her old house and bought land closer to the safety of her natal kin. Anticipating the critique that her home was insecure, Tharini had built a large wall around her property, completing it even before she started work on the house. To help manage her granddaughter's stigma from living with only two small children, Pemawathie slept in the house each night.

Naeaegama villagers condemned women who 'walk around all over', socializing outside the house without clear justification for doing so. Tharini noted that she always gave a reason to her grandmother and other kin when she had to run an errand and left her 
children in their care. However, people reacted critically to one older woman whose husband worked abroad. My research associated noted that her house did not yet have windows (and was thus not a secure place to spend nights), and said that the woman 'was getting too friendly with other women's husbands'. Lakmini openly critiqued her daughterin-law for 'walking everywhere' and even staying away overnight (perhaps as part of her job as a servant); Lakmini found this behaviour especially disturbing because her two unmarried teenage granddaughters lived in that home. Lakmini implied that these girls needed their mother's presence to assure their chastity and needed their mother to behave well herself in order to preserve their marriageability. Another mother in that same compound thanked me repeatedly for constructing an enclosed toilet for the family, because her pre-pubescent daughter could not respectably go alone into the surrounding cinnamon gardens to empty her bowels and bladder. That mother hoped fervently to build a new home that would offer more security than the wood slat structure that she and her family currently inhabited. In these examples, family members expressed concern to protect the reputations of married, unmarried, and divorced female kin.

Stigma from sexual misconduct also affects migrants. Unchaste migrant women risked losing their families. For example, a short newspaper clipping entitled ‘Housemaid Returns with Baby' (Thanthriarachchi 2015: 7) notes that a woman returned from the Middle East with a baby fathered by 'a citizen of that country'. Her husband turned her away and the police could not persuade him to take her back, therefore 'The magistrate ordered the woman and her infant child to be entrusted to the care of her parents and to hand over her eleven year [old] daughter and seven year old son to her husband'. Fierce debates arise around the world about belonging, citizenship, and identity for migrant women's children born in the host country (Constable 2014: 2); in this case the baby also destabilized marital relations and family identity at home for the mother. Indisputable evidence of extramarital 
sexual relations resulted in this woman's loss of her older children and the return of her undisciplined body to her parents for care and supervision.

\section{Mothers' Obligations to Teenage Daughters}

Several recent articles in the English language newspapers sum up cultural expectations for Sri Lankan women. One author asserts that women are tasked with raising children, 'instilling the correct values and principles in them, and bringing them up with an innate sense of responsibility to both community and country'; this same author notes that 'Women are efficient managers of household budgets, childcare, children's education, caring for elderly parents, as well as performing their religious duties' (Chandratilleke 2015: 10). As discussed above in the moral panic discourse around the Family Background Report, press coverage proclaims as fact 'the breakdown of social structure as a result of mothers going for employment in the Middle East' (Weerasooriya 2015: 4). In Naeaegama, people generally supported the view that parents bore the responsible for the formation of their children's characters, but they seemed more concerned with preserving the reputations of teenage daughters than they did with the upbringing of babies and toddlers.

Although mothers did worry about the upbringing of younger children, my interview data suggest that they are more likely to return home in order to safeguard the chastity of daughters who reach puberty. A number of migrants whom I interviewed noted that they curtailed their trips abroad when their daughters came of age. When asked upon her return from Singapore whether she planned to go abroad again, Pemawathie's daughterin-law said that she would remain in Sri Lanka. She remarked, 'My daughter is fourteen, and my son is ten. You have to be careful now not only about girls, but also about boys'. She noted that she wanted to assure that both children continued to study. And her reference to the daughter's age indexed her awareness of her daughter's burgeoning fertility. 
One household clearly illustrates how the status of three generations of female bodies determines one migrant woman's mobility and labour prospects. When I spoke with the household in 2015 while Ramani (introduced above, 42 at that time) was working abroad, her husband (67) noted that they had used her remittances to build an indoor toilet and shower; before this point, the family had used a semi-enclosed shelter in the compound for bathing. With an aging sister-in-law (80) and an unmarried teenage daughter, the family made the investment to bring the bathing facilities indoors. They still needed to complete a cement wall at the back of the compound and plaster the walls of the house inside and outside. When I spoke with Ramani in 2016, she said that she would not go back to Saudi Arabia, even though her employers would like her to return. Although Ramani had been willing to leave her youngest son when she went abroad before, she could not go abroad now, because her daughter had come of age and was studying for her A-level exams and her elderly sister-in-law was in poor health. Before Ramani returned to Sri Lanka, her daughter had helped the sister-in-law bathe in the new bathroom; no male gazes had rested on female bodies. However, the sister-in-law's limited mobility and cognitive decline meant that she could no longer guard the young woman's virtue. In this case, the healthy young woman, not the frail elderly one, required the migrant's care and presence.

The household of six made do financially on Ramani's savings and her husband's pension. Returning to the theme of food referred to earlier with the story about the goat and the bitter gourd, Ramani remarked that the pension provided 'not even enough to feed everyone'. Although Ramani spoke longingly of a migrant's high salary and recruitment bonus, she had made the decision to remain at home and had found a job in a doll factory, where she made about one fifth of the salary that she could have earned abroad. In the future, she would likely need to return to the Middle East in order to earn money to buy land and build a house for her middle son, finish some remaining work on her own house (which the youngest son would inherit), and fund her daughter's dowry. Ramani clearly felt 
the burden of supporting her family financially; her elderly sister-in-law had contributed the land on which the family was living, and her husband had a pension, but none of the other adults in the household were actively employed, and the burden of support fell to her (particularly due to the 25-year age-difference between her and her husband). Though she was physically fit, she could not leave the home to take the most lucrative job abroad due to the bodily states of her daughter and sister-in-law.

\section{Grandmothers}

Women's potential mobility also depends on the marital and reproductive status of their sons and, especially, daughters. For example, in one household the long-term migrant mother, Sarojini told me in 2017 that she had returned home for good. Her younger daughter was engaged to be married and was staying with her parents while her fiancé earned money abroad to construct a house. Her elder daughter was married, had spent a year in Dubai with her migrant husband, and had returned home to have her first baby. Sarojini helped the new mother care for the child.

Although at age 51 Sarojini could legally have returned to her job abroad, she did not think she would go again. She had come home to have a hysterectomy. With both daughters' dowries taken care of and the work on the house finished, she had no additional pressing financial needs to take care of. Her husband, 53, worked as a house painter. Additionally, her mother-in-law, who occupied a small house on the same property, had numerous potentially debilitating health issues (arthritis, diabetes, high blood pressure, and bad eyes) although she remained cognitively sharp and relatively spry. When both daughters left home to live with their husbands, Sarojini said she would need to stay at home to cook for her husband and look after her mother-in-law. As all of the women in the family aged, the younger generation started having children, and Sarojini became a 
grandmother herself, she transitioned from migrant breadwinner to homebound caregiver. Numerous other former migrants in Naeaegama made similar 'kin-timing' transitions from working abroad to caring at home for their children's families.

Women in the grandparent life-stage took pride in their role of looking after grandchildren and facilitating the migration of their sons, daughters, and in-laws. For example, Chandini took care of a passel of grandchildren while two sons and a daughter-inlaw worked abroad. She told me that she untangled her grandchildren's hair, enrolled them in school, transported them daily to and from tuition classes, and made sure they did their homework. She took pride in her accomplishments: 'The teachers say these kids are finebetter than fine! They are better off living with me than they would be living with their own mother. The teachers say not to change a thing!' She favourably contrasted the children she looked after with the children of her middle son. This son and his wife lived with his in-laws in a dilapidated, crowded, older house down the street. Neither spouse held a job, and Chandini claimed that their four children were 'running all over like monkey babies'. In contrast, the families of her migrant sons and daughter made steady progress in building new houses and their children behaved in well-mannered ways. Chandini clearly felt that her kin work enabled the orderly social reproduction of the migrant families. She implicitly contradicted the assumptions inherent in the Family Background Report that only mothers could successfully bring up young children.

Grandmothers stepped into and out of the picture as their families needed their help. For example, a male migrant's mother-in-law had stayed with his wife and three young children for three years while he was abroad in Korea. Upon his return home, his mother-inlaw had moved to one of her other children's homes to help out there, even though he had asked her to stay on. And Presanna (introduced above) came home in 2015 to stay with his 71-year-old mother when his health took a bad turn and his family felt he needed to leave Italy and return to Sri Lanka. Conversely, another mother was quite upset to learn that both 
her daughter and her son-in-law planned to migrate to New Zealand; she felt that the young couple would be better off in Sri Lanka where she and her husband could look after their grandchild (and the daughter and son-in-law could look after the older couple as they aged). As other scholars have pointed out (Buch 2017: 87), 'a good old age' involves a network of close kin, neighbours, and friends. Temporary migration challenges the family to rearrange reproductive labour, but permanent migration entirely undermines reciprocal caregiving obligations.

Grandmothers often worried that their ill health would jeopardize care relations in their households. For example, Kusuma looked after her husband (who had been crippled by a stroke) and her lively three-year-old grandson. In 2016, she had strained her arm badly; despite several months of Ayurvedic treatment, it continued to pain her. She worried that if she could not recover full use of that arm, she would be unable to fulfil her family obligations, necessitating that her daughter-in-law give up her paid employment. Similarly, in 2016, Gayani had fallen and injured her knee, making it difficult for her look after her widowed son and an elderly relative who lived next door. By 2017, Kusuma gladly reported that her arm had recovered. Gayani's knee continued to pain her, but her son had remarried, bringing another able-bodied woman into the household to relieve some of the pressure on Gayani. These examples emphasize the importance of the extended family in all of Naeaegama's households, not merely in migrants' homes.

As members of migrant families move through the life course, grandparents who have facilitated migration in the past know that their kin will do their best to help them when they fall ill and need care. For example, Pemawathie had spent many years taking care of grandchildren in order to enable the migration of her daughter and her daughters-in-law. Aged 65 in 2015, she was active and in good health. Thinking about the future, I asked her 'What would happen if you got sick?' She replied that her kin would help her right away. She said, 'I have always helped everyone, and I have never wasted any money. All the funds 
I had, I used for their development. I only spent on necessities for the grandchildren. When I fall ill, they must help me. If they did not, it would be their pawu (sin, karmic demerit)'. Pemawathie has developed a deep social debt, or 'entrustment' obligation (Coe 2017: 145) with kin who will care for her in her old age. Pemawathie went on to note that even now, despite her good health, her daughters-in-law bring her lunch and make tea for her. Sharing food and physical care indicated close social relationships, and grandmothers who have contributed to the social reproduction of two generations of a family can draw on their cultural capital in their old age.

\section{Conclusion}

As the cases presented here make clear, bodily processes related to food, sex, age, and health are deeply meaningful in understanding working-class migrants' choices and the narratives that they related about their work and lives. Discussions of bodies take place within firmly established gendered discourses that problematize women's migration as detrimental to family well-being and social reproduction. The moral panic emphasizes women's vulnerability to abuse abroad and the adverse effects of their absence on the daughters and husbands left behind.

Migrants' mobility depends not only on the fitness of their own bodies but also on the bodily states of other members of their households, particularly the health of care-giving grandparents and the reproductive status of daughters who have reached puberty or have children. Migrants regulate their own migration with respect to their own and their children's sexuality and reproductive potential, doing their best to safeguard the reputations of daughters and daughters-in-law. Migrant families also arrange their kin so as to make sure that only women see other women's bodies. When elderly women become too frail to 
bathe on their own or to look after the reputations of unmarried granddaughters, migrant female kin often find themselves obliged to come home to provide care.

State policies about migration reflect values and stereotypes circulating in the public sphere. The 2013 Family Background Report policy not only puts brackets around the ages of potential migrants but also restricts their migration depending on the ages of their children and the genders and ages of potential caregivers for these children. The government policy both reflects and influences local assumptions about gender roles, intergenerational obligations, and appropriate behaviour and family structures for people of all ages throughout the life course. Individuals and the state ascribe culturally-specific meanings to the biological processes that bodies undergo. Bodily changes over time related to sexuality, reproduction, and care needs affect when and whether people are willing and able to leave home and cross borders.

\section{Bibliography}

Bernard, H. Russell. 2011. Research Methods in Anthropology: Qualitative and Quantitative Approaches. $5^{\text {th }}$ edn. Blue Ridge Summit: AltaMira Press.

Biolsi, Thomas. 2007. 'Race Technologies'. In A Companion to the Anthropology of Politics, edited by David Nugent and Joan Vincent. 400-417. Oxford: Blackwell Publishing.

Brown, Bernardo. 2011. 'Indifference with Sri Lankan Migrants'. Ethnology 50(1):43-58.

Brown, Diana De G. 2013. “"I Have to Stay Healthy”: Elder Caregiving and the Third Age in a Brazilian Community'. In Transitions and Transformations: Cultural Perspectives on Aging and the Life Course, edited by Jason Danely and Caitrin Lynch. 123-136. New York: Berghahn Books. 
Buch, Elana D. 2017. ‘Beyond Independence: Older Chicagoans Living Valued Lives'. In Successful Aging as Contemporary Obsession: Global Perspectives, edited by Sarah Lamb. 85-97. New Brunswick: Rutgers University Press.

Chandratilleke, Ranee. 2015. 'Women: Greener Pastures Come Home'. Daily Mirror, p. 10. 4 August, 2015.

Coe, Cati. 2017. ‘Returning Home: The Retirement Strategies of Aging Ghanaian Care Workers'. In Transnational Aging and Reconfigurations of Kin Work, edited by Parin Dossa and Cati Coe. 141-158. New Brunswick: Rutgers University Press.

Cole, Jennifer and Deborah Durham. 2007. 'Introduction: Age, Regeneration, and the Intimate Politics of Globalization'. In Generations and Globalization: Youth, Age, and Family in the New World Economy, edited by Jennifer Cole and Deborah Durham. 128. Bloomington: Indiana University Press.

Constable, Nicole. 2014. Born Out of Place: Migrant Mothers and the Politics of International Labor. Hong Kong: Hong Kong University Press.

Daily Mirror. 2015a. 'Editorial: Stop the Abuse of Lankan Mothers and Girls'. Daily Mirror, 25 July, 2015. P. A8.

Daily Mirror. 2015b. 'Employer offers SL maid for sale online in Saudi'. Daily Mirror, 4 August, 2015. P. A4.

Daily News. 2018. 'Family Background Report for Housemaids: Law to be Amended'. Daily News. 5 September, 2018. Accessed 7 April, 2019. Available online: http://www.dailynews.lk/ 2018/09/05/political/161738/parliament.

Dossa, Parin and Cati Coe. 2017. 'Introduction: Transnational Aging and Reconfigurations of Kin Work'. In Transnational Aging and Reconfigurations of Kin Work, edited by Parin Dossa and Cati Coe. 1-24. New Brunswick: Rutgers University Press. 
Douglass, Mike. 2014. 'Afterword: Global Householding and Social Reproduction in Asia'. Geoforum 51: 313-316.

Evans, Becky. 2013. 'Saudi Arabia Beheads Maid for Murdering Baby... Despite Defendant Being Just 17 When Child Died'. Daily Mail Online. Posted 7 February 2013; accessed on 26 March, 2018. http:/ / www.dailymail.co.uk/news/article-2259967/SaudiArabia-beheads-maid-Rizana-Nafeek-murdering-baby.html.

Frantz, Elizabeth. 2008. ‘Of Maids and Madams: Sri Lankan Domestic Workers and their Employers in Jordan'. Critical Asian Studies 40(4): 609-638.

Gamburd, Michele R. 2000. The Kitchen Spoon's Handle: Transnationalism and Sri Lanka's Migrant Housemaids. Ithaca: Cornell University Press.

Gamburd, Michele R. 2005. “'Lentils There, Lentils Here': Sri Lankan Domestic Labour in the Middle East". In Asian Women as Transnational Domestic Workers, edited by Shirlena Huang, Brenda S.A. Yeoh, and Noor Abdul Rahman, 92-114. Singapore: Marshall Cavendish.

Gamburd, Michele R. 2008. Breaking the Ashes: The Culture of Illicit Liquor in Sri Lanka. Ithaca: Cornell University Press.

Gamburd, Michele R. 2013. ‘Care Work and Property Transfers: Intergenerational Family Obligations in Sri Lanka'. In Transitions and Transformations: Cultural Perspectives on Aging and the Life Course, edited by Jason Danely and Caitrin Lynch. 151-167. New York: Berghahn Books.

Gamburd, Michele R. 2015. 'Migrant Remittances, Population Ageing and Intergenerational Family Obligations in Sri Lanka'. In Transnational Labour Migration, Remittances and the Changing Family in Asia, edited by Lan Anh Hoang and Brenda Yeoh. 139-164. New York: Palgrave. 
Gamburd, Michele R. 2019. 'Migrant Emplacement: Gendered Subjects, State Regulations, and the Discursive Erasure of Elders in Sri Lanka'. In Caring for Old Age, edited by Roberta Mandoki. Heidelberg: Heidelberg University Press.

Huijsmans, Roy. 2013. “"Doing Gendered Age”: Older Mothers and Migrant Daughters Negotiating Care Work in Rural Lao PDR and Thailand'. Third World Quarterly 34(10): 1896-1910.

Ibarra, Maria de la Luz. 2002. 'Transnational Identity Formation and Mexican Immigrant Women's Ethics of Elder Care'. Anthropology of Work Review 23(3-4): 16-20.

ILO. 2018. Sri Lankan Female Migrant Workers and the Family Background Report. Colombo: International Labour Organization Country Office for Sri Lanka and the Maldives. Lloyd-Sherlock, Peter and Catherine Locke. 2008. 'Vulnerable Relations: Life-Course, Wellbeing, and Social Exclusion in Buenos Aires, Argentina'. Ageing and Society 28(6): 779-803.

Locke, Catherine, Janet Seeley, and Nitya Rao. 2013. 'Migration and Social Reproduction at Critical Junctures in Family Life Course'. Third World Quarterly 34(10): 1881-1895. Lynch, Caitrin. 2007. Juki Girls, Good Girls: Gender and Cultural Politics in Sri Lanka's Global Garment Industry. Ithaca: Cornell University Press.

Ministry of Foreign Employment. 2015. 'Ministry Circular 2015/1: Obtaining a Report on the Family Background of Women Who Expect to Migrate for Employment'. Colombo: Sri Lanka. Accessed on 9 March 2016.

http://www.foreignemploymin.gov.lk/downloads/Circulars/English.pdf.

Näre, Lena. 2010. ‘Sri Lankan Men Working as Cleaners and Carers: Negotiating Masculinity in Naples'. Men and Masculinities 13: 65-86.

Ruwanpura, Eshani Samantha. 2011. 'Sex or Sensibility? The Making of Chaste Women and Promiscuous Men in a Sri Lankan University Setting'. Edinburgh: PhD diss., University of Edinburgh. 
Sirisena, Mihirini. 2018. The Making and Meaning of Relationships in Sri Lanka: An Ethnography on University Students in Colombo. New York: Palgrave.

Sri Lankan Bureau of Foreign Employment. 2017. Annual Statistical Report of Foreign

Employment-2016. Battaramula, Sri Lanka: SLBFE. Accessed on 26 March 2018.

http:/ / www.slbfe.lk/file.php?FID=68.

Sri Lankan Bureau of Foreign Employment. 2014. Annual Statistical Report of Foreign

Employment-2013. Battaramula, Sri Lanka: SLBFE. Accessed on 28 March 2018.

http:/ / www.slbfe.lk/ file.php?FID=177

Sugathapala, D.G. 2015. 'School Girl Sexually Abused'. Daily Mirror, 5 August 2015/.p. A5.

Sunday Observer. 2018. 'Contraception Mandatory for Lankan Migrant Workers?' Sunday

Observer, 8 April, 2018, p. 17.

Sunday Times. 2013. ‘Lankan Women's Groups Dismayed by Restrictive Rule for Female Migrant Workers'. Sunday Times Business Section. Posted 29 September. Accessed on 9 March 2016. http:/ / www.sundaytimes.lk/130929/business-times/lankanwomens-groups-dismayed-by-restrictive-rule-for-female-migrant-workers63592.html.

Thanthriarachchi, Sunil S. 2015. 'Housemaid Returns with Baby”. Daily Mirror, 3 August, 2015, p. 7.

United Nations. 2014. Letter from the Office of the High Commissioner for Human Rights, to the Permanent Mission of the Democratic Socialist Republic of Sri Lanka. Reference AL G/SO 214 (106-10) LKA 1/2014. 28 January.

United Nations. 2015. Sri Lankan Migrant Domestic Workers: The Impact of Sri Lankan Policies on Workers' Right to Freely Access Employment. Colombo, Sri Lanka: United Nations Sri Lanka 
Weerasooriya, Nayomini. 2015. 'Are Women Adequately Represented in Sri Lanka's Political Space?' Daily Mirror Business, 24 July, 2015, p. 4.

Wettasinghe, Chandradeepa. 2015. 'Major Foreign Debt Restructuring Move after Elections'. Daily Mirror Business, 3 August, 2015, p. 1.

Whyte, Susan Reynolds. 2017. 'Epilogue: Successful Aging and Desired Interdependence'. In Successful Aging as Contemporary Obsession: Global Perspectives, edited by Sarah Lamb, 243-248. New Brunswick: Rutgers University Press.

Williams, Raymond. 1977. Marxism and Literature. Oxford: Oxford University Press.

Zhou, Yanqiu Rachel. 2017. 'The New Aging Trajectories of Chinese Grandparents in Canada'. In Transnational Aging and Reconfigurations of Kin Work, edited by Parin Dossa and Cati Coe. 43-60. New Brunswick: Rutgers University Press. 
